\title{
Control System Design Guide
}

\section{Element 5-Integrated Commissioning and Diagnostics}

Project 2.1 Commissioning and Monitoring for New Construction

Developed by:

David Sellers, Hannah Friedman, Tudi Haasl

Portland Energy Conservation, Inc.

1400 SW 5th Avenue, Suite 700

Portland, OR 97201

Norman Bourassa and Mary Ann Piette

Lawrence Berkeley National Laboratory

1 Cyclotron Road

Berkeley, CA 94720

May 2003
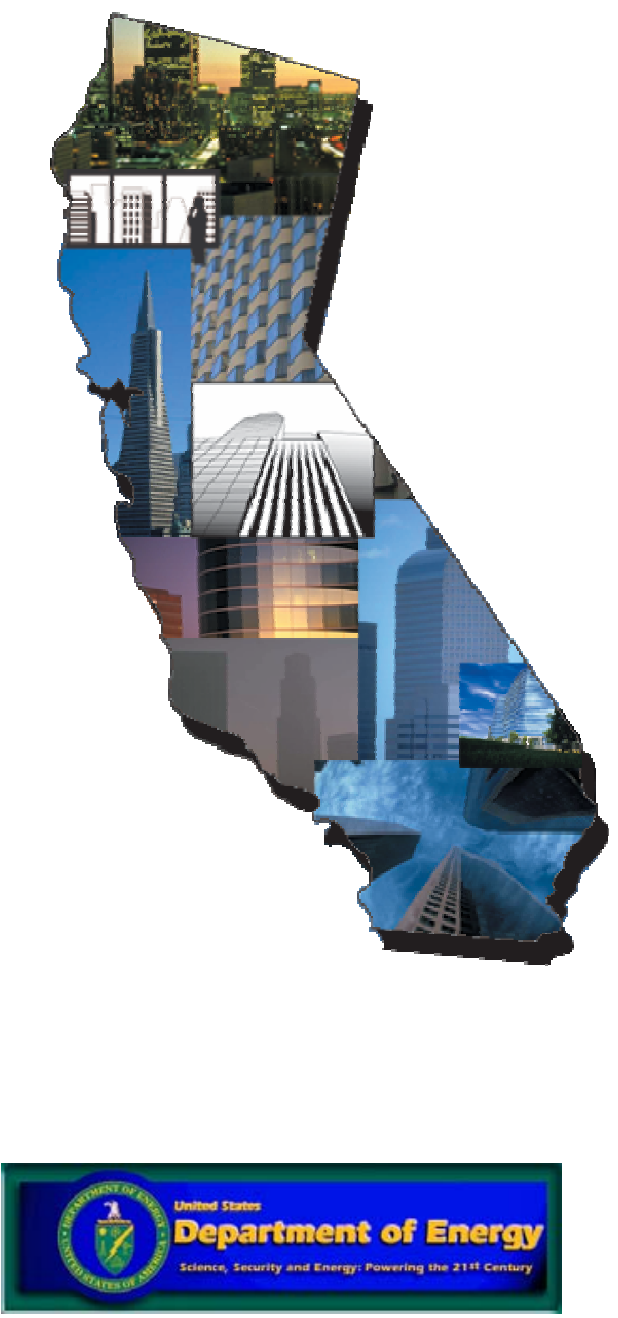


\section{Table of Contents: Control System Design Guide}

How to Use the Design Guide

- Control System Design Process

Selection and Installation of Control and Monitoring Points

System Configurations

\section{Acknowledgements}

This work has been supported by:

- The California Energy Commission's (CEC), Public Interest Energy Research Program, under Contract No. 400-99-012.

- The Assistant Secretary for Energy Efficiency and Renewable Energy, Office of Building Technology, State and Community Programs, Building Technologies Program of the U.S. Department of Energy (DOE) under Contract No. DE-AC0376 SF00098.

Special thanks to Martha Brook (CEC) and David Hansen (DOE). Appreciation is extended to Marti Frank of PECI for her assistance.

Technical review was provided by the following experts:

Gretchen Coleman, P.E., Engineering Economics, Inc. (EEI)

Karl Stum, P.E., CH2M HILL

Steven Taylor, P.E., Taylor Engineering, LLC 


\section{DISCLAIMER}

This document was prepared as an account of work sponsored by the United States Government. While this document is believed to contain correct information, neither the United States Government nor any agency thereof, nor The Regents of the University of California, nor any of their employees, makes any warranty, express or implied, or assumes any legal responsibility for the accuracy, completeness, or usefulness of any information, apparatus, product, or process disclosed, or represents that its use would not infringe privately owned rights. Reference herein to any specific commercial product, process, or service by its trade name, trademark, manufacturer, or otherwise, does not necessarily constitute or imply its endorsement, recommendation, or favoring by the United States Government or any agency thereof, or The Regents of the University of California. The views and opinions of authors expressed herein do not necessarily state or reflect those of the United States Government or any agency thereof, or The Regents of the University of California.

This report was prepared as a result of work sponsored by the California Energy Commission (Commission). It does not necessarily represent the views of the Commission, its employees, or the State of California. The Commission, the State of California, its employees, contractors, and subcontractors make no warranty, express or implied, and assume no legal liability for the information in this report; nor does any party represent that the use of this information will not infringe upon privately owned rights. This report has not been approved or disapproved by the Commission nor has the Commission passed upon the accuracy or adequacy of the information in this report.

ERNEST ORLANDO LAWRENCE BERKELEY NATIONAL LABORATORY IS AN EQUAL OPPORTUNITY EMPLOYER. 